\title{
COMMUNITY EMPOWERMENT THROUGH PRODUCT DISPLAY DESIGN FOR THEMATIC BOOTH DISPLAY AT THE EXHIBITION AREA IN TOURISM VILLAGE - SOUTH BANDUNG
}

\author{
Titi INDAHYANI*, Yunida SOFIANA, Mila SAVITRI and Rr. Ratna A. RAHAYU \\ Interior Design Department, School of Design, Bina Nusantara University, Jakarta, Indonesia \\ *tindahyani@binus.edu
}

\begin{abstract}
During the pandemic, the sustainability of MSME businesses and communities that produce superior tourism village products crucially need an effective promotion and marketing strategy, including through virtual exhibitions. The virtual exhibition is expected to expand the local market area and support increased sales of various superior products through online networking channels. In this case, product display planning and layout arrangement of several booth categories that are part of the virtual exhibition is very important because it can strengthen the characteristics, uniqueness of the product and be able to add value to the products displayed while promoting the tourist village. The general objective of this community partnership program is to hold an exhibition of superior products of tourist villages by using several categories of furniture to support product displays. This program will apply knowledge about structuring booth categories for various superior products in a virtual exhibitions which are more flexible and thematic in nature. It is expectedthat through understanding the arrangement of display booths in an exhibition can supportvillage communities, especially farmer groups, social organization that empowers women to participate in the development of Indonesia (PKK). and Youth Organizations to produce display arrangements and display booth designs in an exhibition that is suitable for the products of tourist villages in the tourist village of Pasirmulya. This program will be in the form of training in managing three categories of superior product for tourist villages in Pasirmulya: culinary, fashion and crafts. The method that will be used is to collect literature data on various display booth layouts as well as data about virtual exhibitions including superior products, as well as observing opportunities and target markets. Furthermore, a field survey will be carried out to record the condition of the location that will be used as the location of the exhibition as well as interviews with partners as supporting data collection. The end result of this programis display arrangement skills training for each product in an exhibition to strengthen the identity of a tourist village, improve product marketing and as a MSME business sustainability, especially in Pasirmulya village
\end{abstract}

Keywords: Virtual Exhibition, Tourism Village Sustainability, Display Booth, Tourist Village Souvenirs, Village Community Empowerment

\section{BACKGROUND}

As a tourism village, the majority of people in Pasirmulya Village are farmers, especially coffee farmers. In addition to the beautiful natural scenery, this village has a superior Arabica Coffee product (Puntang Coffee) which is internationally recognized. In addition, Pasirmulya village also has other localpotentials that can be developed, such as culinary, fashion and crafts. The potential that exists in this community can be developed into a variety of superior products for the tourist village's in Pasirmulya's tourism village.

The empowerment program in Pasirmulya village had previously been carried out in two stages. The first stage is the development of various souvenir products through the potential for sewing skills using manualy patchwork applications technique. The second stage is training on the design of display carts to be used to display typical tourist village souvenirs that can be placed flexibly in various strategic areas in tourist villa ges. As an effort to support the promotion of tourism sustainability in the tourist village of Pasirmulya during the pandemic, it is very important to develop a marketing strategy for the village's superior products that are displayed attractively through thematic booth

\section{METHODS}

As an effort to overcome the problem of limited promotion and marketing networks for superior products typical of the Tourism Village in Pasirmulya Village, the solution offered is to organize training in managing three categories of superior products, namely culinary, fashion and craft in a joint exhibition that is a lso connected to a virtual exhibition. Prior to the training, a field survey wasconducted to see the various potential exhibition locations in Pasirmulya village. The stages are as follows:

Based on the survey results, a suitable exhibition location will be chosen for the flagship product exhibition which will also be connected to the virtual exhibition.

The layout of several booths in the exhibition area will be designed with a booth design that is tailored for the needs of culinary, fashion and craft products. While the design process is running, training will be conducted for the community of Pasirmulya village and its surroundings which will be divided into several training sessions, such as: a) Introduction of booth display. b) Training on managing culinary, fashion and craft products at the booth. c) Training on the application of a unique coffee theme for each booth based on product category using local materials. d) Application of booths in the exhibition area with an ergonomic layout.

Because the exhibition will be connected to the virtual exhibition, the trainees will be equipped with knowledge related to virtual exhibitions. An evaluation of the program implementation will be carried out by monitoring the understanding and skils of the Partners before and after the training as well as the response of the surrounding community including visitors who come directly to Tourism Villages and those who visit virtual exhibitions. Basic stage assistance will be carried out periodically for 2 months in response to existing ma rket opportunities. 


\section{RESULT AND DISCUSSION}

\section{The potential and Challenges of Pasirmulya village as a tourism village}

Tourism village is a form of integration between attractions, supporting facilities, and accommodations that are displayed in social life that is integrated with applicable traditions and procedures (Hawaniar, M and Suprihardjo, $\mathrm{R}, 2013)$. Meanwhile, the main activity in rural areas is agriculture, including economic activities, natural resource management, setting up residential areas, social services and government services (Yotuwu, J.M, 2015). Tourism village as one of nature tourism, can take advantage of local potential to further develop tourist village. In one of the villages in South Bandung, namely in the village of Pasirmulya, there are several aspects that support the tourism village program, namely: 1) the potential for natural beauty, including beautiful pine forests and dense Mount Puntang which is a tourist destination. The potential for natural beauty is also supported by the readiness of the community to manage homestay programs around tourist destinations. 2) the potential of plantation and agricultural products, especially coffee. Coffee products from Pasirmulya village are superior products and have been widely known both locally and internationally. 3) The potential of creative products from waste materials originating from several creative centers in Pasirmulya Village which produces waste such as coffee, leather and fashion waste. This waste has the potential to be developed into a superior product for eco -friendly village souvenirs. 4) the potential of human resources, especially the potential of partners consisting of the women's community (PKK and farmers) and the youth community (Ka rang Taruna) who already have basic sewing skills and make souvenirs from the previous empowerment program.

The potentials mentioned above can certainly be optimized through activities to increase the knowledge and skils of local communities aimed at increasing arts and culture as well as environmental awareness. This activity will be supported by marketing strategies and product promotions and integrated tourism village programs. One of the integrated activities that can be carried out by local communities during the pandemic is holding independent and virtual product exhibitions. Partners can market their products through exhibitions or creative bazaars held in the Tourism Village and surrounding areas. During this pandemic, the exhibition will be in the form of a virtual exhibition which will also be published through social media. The main problems for Partners in the Tourism Village in Pasirmulya include 3 things, namely: First, the lack of activities that can support the promotion and marketing of superior products, especially during the pandemic, which is carried out together and continuously with different special themes. in every operation. Second, training is still needed to organize products thematicaly in a joint product exhibition. Third, there is still a need for training in arranging interiors and thematic booths at an exhibition at a real location that can also be connected to a virtual exhibit ion. Based on the partnership conditions, it is hoped that this community empowerment program can be followed by partners and their members. The purpose of this empowerment programis to provide training in managing three categories of superior products, namely culinary, fashion and craft with various themes in a joint exhibition. It is hoped that the training participants will gain additional skills in the field of arranging products with various themes that can strengthen the characteristics and uniqueness of the product so that they can provide added value by following instructions and guidance during training activities. As a continuation of the program, it is also hoped that the training participants can pass on their new knowledge to the surrounding community who still need it. This program is expected to provide a wareness for the tourism village community and its surroundings of the importance of knowledge and skills related to the arrangement of superior products in the booth which is part of a joint exhibition which will be widely published in the form of a virtual exhibition.

\section{Virtual exhibition for MSMEs in the tourism village of Pasirmulya during the pandemic}

In relation to the tourism industry, exhibitions are included in the convention tourism business, according to the Decree of the Minister of Tourism, Post and Telecommunication No. KM. 108 / HM. 703 / MPPT-91, Chapter I, Article 1c, "Exhibition is an activity to disseminate information and promotions related to the holding of conventionsor those related to tourism." While Desthiani U \& Suwandi (2019) concluded that exhibitions are "An activity promotions carried out by producers, groups, organizations, certain associations in the form of displaying product displays to potential relations or buyers. Furthermore, it was also stated that holding an exhibition has benefits such asgenerating opportunities for the development of small and medium-sized businesses and is a good method to open and create tourist destinationsinto business centers that can attract visitors to an area. Furthermore, in addition to contributing to job creation, exhibition activities also have a recreational function, exhibition activities provide a sense of pleasure and entertainment. By watching the exhibition, visitors and observers become calm, happy, and enlightened and fulfill one of the functions of art, namely as a cathartic (psychiatrist). The existence of exhibition activities also has a positive impact on the economy that can be felt by many parties. (Desthiani U \& Suwandi, 2019).

In relation to the prolonged pandemic period, many tourism sectors, including Pasirmulya village as one of the tourist villages, were also affected by this condition which is feared to have a negative effect on the sustainability of micro and small businesses and the welfare of the community. As a result, the marketing and promotion of superior village products, which could originally be done through exhibitions, expos, festivals and bazaars, became constrained due to limited activities in public areas during the pandemic. On the other hand, exhibition activities for superior productsare still one of the activities that can revive the economy in 
tourist villages and help increase sales and promotion of village community products. Considering that tourist villages have limited funding to participate in various exhibition events and bazaars in various locations coupled with the pandemic situation that limits the mobility of activities, this empowerment program is focused on Pasirmulya Village so that the community can hold virtual exhibitions that can also be directly connected to exhibitions at the location. The exhibition area is planned at the location of the Graha Budaya multi-purpose area in Pasirmulya village.

Virtual exhibitions have actually started to be held frequently along with the development of technology in the industrial era 4.0. Along with the emergence of the covid-19 pandemic which resulted in exhibition activities in general not being able to be ca rried out directly on location, virtual exhibitions were increasingly in demand as a solution amid the prohibition of crowding when there were restrictions on mobility in public areas. Virtual exhibitions are held the same asexhibitions in general. The difference is that the organizers are obliged to provide all digital facilities during the exhibition activities for participants, visitors and the organizing committee. The features on the platform that are generally provided in virtual exhibitions, namely the Event Organizer feature, the Exhibitor feature and the Visitor feature. The presence of holding virtual exhibitions has the potential to boost the economy during this pandemic and have a positive impact on the sustainability of the MSME business.

\section{Thematic Booth display at the exhibition}

The development of exhibition booths in this modern era is growing rapidly. Moreover, over time, technology is increasingly developing towards more efficient. This has resulted in the community also switching to virtual which of course requires a booth that can support product excellence. According to Didi (2017), an exhibition booth is a stand or place that is usually used to promote an item or service in an exhibition such as shows, exhibitions, fairs, expos, bazaars, and others. The booth must of course have its own uniqueness so that visitors are interested in stopping by and seeing the products or services provided. This is because, the booth is a representation of acompany, institution, organization, and so on which aims as a promotional medium. To make visitors interested or curious, efforts must be made in terms of design. In terms of design can be in the form of shapes and colors. Attractive and different forms from booths in general, as well as striking color choices can attract the attention of visitors to stop by, ask questions, and even buy products. Therefore, the booth design must be considered in a promotional event at an event or exhibition. Physically, the exhibition booth is a design as a representation of the owner (company, institution, organization, etc.) and functionsas the vanguard of marketing. Using a booth, the marketing process that occurs is direct selling, both goods and services. Booths in an exhibition function as a promotional place to attract consumers and become a lia ison for the activities of sellers and buyers. For this reason, in terms of design, efforts must be made to make the booth or stand look attractive and make consumers curious and interested in visiting.

The use of a theme in an exhibition is also important for increasing sales (The trade show network, 2021). The thematic booth display in this empowerment program is a booth design designed with creative ideas inspired which is a combination of the characteristics of a tourist village and the products that will be displayed with the concept of the overall theme of the exhibition. The application of the thematic booth display is expected to remind the concept of the displayed product so that it will always be in the memory of the client through an unforgettable experience. This experience can be achieved through the use of a variety of flexible materials, innovative techniques, and the latest equipment (displayart, 2021). Thematic booth display also optimizes the concept, characteristics and product identity to offer a variety of environmental concepts or atmospheres ranging from agriculture to beaches that are full of surprises to the public. All booth elements are optimally designed to offer users a quality experience that they will always remember, from the stand structure to the graphic components, decorations, layouts and furniture styles to produce engaging thematic projects.

Given the limited time for implementing the program, including funding for this program, the technical exhibition of the flagship product of the Pasirmulya Tourism Village will use a free virtual exhibition $\mathrm{p}$ latform as a Pilot Project. The exhibition will carry the big theme of Coffee as a characteristic of the superior product of Pasirmulya Villa ge. Coffee is the design inspiration for the thematic booth display and will be a big theme for the virtual exhibit ion of superior products from the tourist village in Pasirmulya. The thematic display booth design for superior products in Pasirmulya Village takes the characteristic form of coffee as one of the typical products of this tourist village. The shape of the coffee is used as the basic inspiration for the design of the souvenir rack (picture 1). As one of the superior products, coffee is a typical product of the Pasirmulya tourist village that will be easily remembered by exhibition visitors. The material used is bamboo with a simple bamboo woven technique that can be produced by the local community. The bamboo was chosen because besides being widely available in Pasirmulya village, bamboo is a lso a renewable environmentally friendly material.

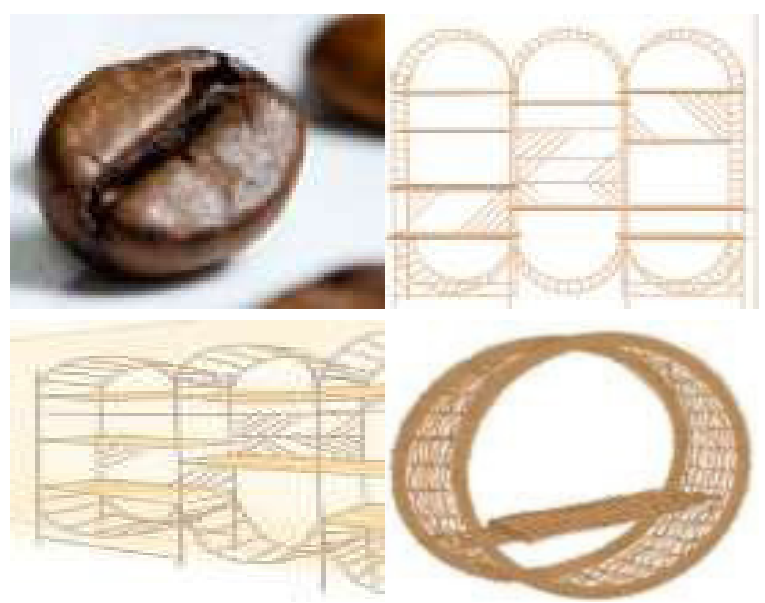

Picture 1 
The souvenir shelves in Figure 1 will be arranged in several display booths in the exhibition area (Figure 2). The products that will be displayed are representatives of 3 creative sub-sectors, namely culinary, craft and fashion. Culinary will feature dry food and beverage products, especially coffee beans and ground coffee. Meanwhile, the craft will feature new products, souvenirs typical of the Pasirmulya tourist village, which are specially designed with design inspiration coming from the local uniqueness of the Pasirmulya village. Meanwhile, fashion will feature bags, pouches, drawstrings, tote bags, wallets and other products that are done using simple techniques.

The Thematic Booth display is designed as a step in educating the public to participate in the sustainability of local tourism preservation. This display booth facility is also a facility that can add value to the product when displayed and contribute to strengthening memories of this tourist village in Pasirmulya for visitors who attend either directly on location or virtually.

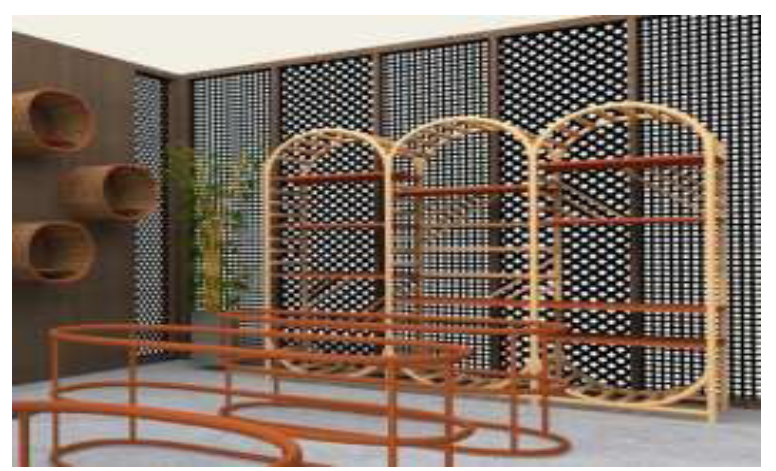

Picture 2

\section{CONCLUSION}

This community empowerment program contributes in terms of supporting tourism promotion in Tourism Villa ges through a thematic display booths and exhibition areas with unique themes to attracttourism villages. This program is also expected to support the preservation of local culture, explore the local strengths of the village as design inspiration, and organize onsite and virtual exhibitions with distinctive themes that strengthen the identity of the Pasirmulya Tourism Village. Another contribution to the local community is improving the welfare of the community, through training and mentoring skills of partners. With this program, it is expected that there will be an increase in local product sales through attractive and effective display arrangements and exhibition themes for promotion and marketing of superior products. Finally, the exhibition might have an impact on the sustainability of the tourism sector and an increase in the number of tourists visiting the tourism village of Pasirmulya,

\section{REFERENCES}

Collins-kreiner, Noga and Yael Zins (2011) "Tourists and Souvenirs: Changes through Time, Space and Meaning," Journal of Heritage Tourism, vol. 6, no. 1, p. 17-27.

Desthiani, U. \& Suwandi (2019). MICE (Meeting, Incentive, Convention, Exhibition). Banten: Unpam Press
Displayart (2021). Thematic Booth. Retrieved on July 21 from: https://www.displayart.com.mx/en/thematic-booth/ Drake, S (1991). Local Participation in Ecotorism Project, in Nature Tourism. Washington D.C.: Island Press. p. 132 Epler Wood, M.(1991). Global Solutions: on Ecotourism Society, in Nature Toursim. Washington D.C.: Islang Press. P.204.

Hawaniar, M \& Suprihardjo, R (2013). Kriteria Pengembangan Desa Slopeng sebagai Desa Wisata di Kabupaten Sumenep. Jurnal Teknik Pomits Vol. 2, No. 3, (2013) ISSN: 2337-3539 (2301-9271 Print). http://download.portalgaruda.org/article. php?article $=133581 \&$ val $=4186$

Kesrul, M. (2004). Meetting, incentive trip, conference, exhibition / M. Kesrul. Yogyakarta : Graha Ilmu,.

Kim, Soyoung and Mary A. Littrell(1999) "Predicting Souvenir Purchase Intentions," Journal of Travel Research, vol. 38, no. 2, p. 153-162.

Lise Hérouxand Nancy J. Church. (2014) Marketing Strategies of Gift and Souvenir Shopsin Canada and the United States, Téoros [Online], 33, 2 | 2014, Online since 12 January 2016, connection on 08 August 2019. URL : http://journals.openedition.org/teoros/2653

Nuryanti, Wiendu(1993). Concept, Perspective and Challenges, Part of InternationalConference Report on Culture Tourism. Yogyakarta, Gadjah Mada University Press.

Rosenbaum, Mark S. and Daniel L. Spears (2005) "Who Buys What? Who Does What? Analysis of Cross-Cultural Consumption Behaviors Among Tourists in Hawaii," Journal of Vacation Marketing, vol. 11, no. 3, p. 235-247.

Solberg Søilen, K. (2013). Exhibit Marketing and Trade Show Intelligence: Successful Boothmanship and Booth Design. Springer Science \& Business Media.

Trejos,B.Chiang,LHN.(2009). Local Economic Lingkages to Community-based Tourism in Rural Costa Rica. Singapore Journal of Tropical Geography. 30(3): 373387.

Yoltuwu, J (2015). Sosialisasi Pelaksanaan UU No.6 Tahun 2014 Tentang Desa. Retrieved fromhttps:// www.kemenkopmk.go.id/sites/default/files/field/ file_pendukung/Kewenangan\%20Tupoksi\%20Ditje n\%20PKP_2015.pdf

The trade show network(2021). The Power of A Theme: Tradeshow Network. Retrieved on July 21, from https:/www.thetradeshownetwork.com/trade-showblog/the-power-of-a-themed-trade-show-exhibit

V Cube (2021). Virtual Exhibition Platform . Retrieved from: https://vcube.co.id/en/virtual-exhibition/

Wangun-Bandung. ICCD, Vol.1, no. 1, p.290-294. URL : https://iccd.asia/ojs/index.php/iccd/article/view/44/44 